\title{
Sulfadiazine, sulfamethazine and sulfachloropyridazine removal using three different porous materials: Pine bark, "oak ash" and mussel shell
}

\author{
M. Conde-Cid ${ }^{\text {a }}$, R. Cela-Dablanca ${ }^{\mathrm{b}}$, G. Ferreira-Coelho ${ }^{\mathrm{b}}$, D. Fernández-Calviño ${ }^{\mathrm{a}}$, \\ A. Núñez-Delgado ${ }^{\text {b, }}$, M.J. Fernández-Sanjurjo ${ }^{\text {b }}$, M. Arias-Estévez ${ }^{\mathrm{a}}$, E. Álvarez-Rodríguez ${ }^{\mathrm{b}}$ \\ ${ }^{a}$ Soil Science and Agricultural Chemistry, Fac. Sciences, Univ. Vigo, 32004, Ourense, Spain \\ ${ }^{\mathrm{b}}$ Dept. Soil Science and Agricultural Chemistry, Engineering Polytechnic School, Univ. Santiago de Compostela, 27002, Lugo, Spain
}

\section{A R T I C L E I N F O}

\section{Keywords:}

Sulfonamides

Batch experiments

Oak ash

Mussel shell

Pine bark

Adsorption/desorption

\begin{abstract}
A B S T R A C T
This work focuses on studying the efficacy of three different by-products to adsorb three antibiotics (sulfadiazine, SDZ; sulfamethazine, SMT; sulfachloropyridazine, SCP). These antibiotics can be considered pollutants of the environment when they reach water, as well as in cases where they are spread on soils through irrigation or contained in sewage sludge or livestock manure. In this study, batch-type adsorption/desorption experiments were performed for each of the three sulfonamides, adding 7 different concentrations of the antibiotics, going from 1 to $50 \mu \mathrm{mol} \mathrm{L}-1$, and with contact time of $24 \mathrm{~h}$. The results indicate that pine bark is the most efficient bioadsorbent among those studied, as it adsorbs up to $95 \%$ of the antibiotics added, while desorption is always less than $11 \%$. However, for "oak ash" and mussel shell the adsorption is always lower than 45 and $15 \%$, respectively, and desorption is high, reaching up to $49 \%$ from "oak ash" and up to $81 \%$ from mussel shell. Adsorption data showed good fitting to the Linear and Freundlich models, with $\mathrm{R}^{2}$ values between 0.98 and 1.00 in both cases. $K_{d}$ and $K_{F}$ adsorption parameters showed similar values for the same sorbent materials but were much higher for pine bark than for the other two bioadsorbents. The Freundlich's $n$ parameter showed values in the range $0.81-1.28$. The highest $K_{F}$ values (and therefore the highest adsorption capacities) were obtained for the antibiotic SCP in pine bark. Pine bark showed the highest capacity to adsorb each of the antibiotics, increasing as a function of the concentration added. When the concentration of sulfonamide added was $50 \mu \mathrm{M}$, the amounts adsorbed were $780 \mu \mathrm{mol} \mathrm{kg}{ }^{-1}$ for SDZ, $890 \mu \mathrm{mol} \mathrm{kg}^{-1}$ for SMT, and $870 \mu \mathrm{mol} \mathrm{kg}{ }^{-1}$ for SCP. "Oak ash" and mussel shell have low adsorption capacity for all three sulfonamides, showing values always lower than

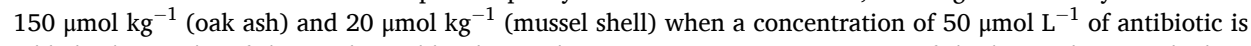
added. The results of this study could aid to make an appropriate management of the by-products studied, in order to facilitate their valorization and recycling in the treatment of environmental compartments polluted with sulfonamide antibiotics.
\end{abstract}

\section{Introduction}

In recent years, the concern about environmental pollution due to antibiotics and other emerging contaminants has clearly increased (Conde-Cid et al., 2018; Jechalke et al., 2014; Lou et al., 2018; Paolotti et al., 2016; Ramírez-Malule et al., 2020; Rasheed et al., 2019).

The higher consumption of antibiotics in veterinary medicine is closely related to the proliferation of intensive livestock systems, which demand these drugs to treat and prevent diseases, and even, in some countries, to promote animal growth (Spielmeyer et al., 2017). Subsequently, these compounds can reach the environment, mainly due to the spreading of manure and slurries onto soils, since up to $90 \%$ of the antibiotic can be excreted through feces and urine (Qiao et al., 2018; Szymańska et al., 2019). A significant percentage of the antibiotics used in human medicine are also excreted through feces and urine, and can reach the soil through irrigation with wastewater or by fertilization with sewage sludge (Yang et al., 2016). Once into the soil, antibiotics can pass to surface and groundwater, enter the trophic chain (Carvalho and Santos, 2016; Yi et al., 2019), and cause an increase in the resistance of bacteria to these drugs, which is considered a very worrying public health problem (Alduina, 2020; Singer et al., 2016).

Within antibiotics, sulfonamides are widely used in veterinary and

\footnotetext{
* Corresponding author.

E-mail address: avelino.nunez@usc.es (A. Núñez-Delgado).
} 
human medicine, since they present a broad spectrum against most Gram (+) and Gram (-) bacteria (Yang et al., 2016). However, these antibiotics are associated to potential risks when they are present in soils and waters, even at low concentrations (Lahcen and Amine, 2018). Since most conventional wastewater treatment plants are not effective enough removing antibiotics (Barber et al., 2009; Yang et al., 2016), sulfonamides have been found in the effluents and sludge of most of these treatment plants (Yang et al., 2016). In addition, these antibiotics have been detected in animal manure and slurries (Conde-Cid et al., 2018). In fact, our previous research has reported on the presence of sulfonamides in soils fertilized with manure from different animals (cattle, pigs and poultry) in concentrations of up to $0.2 \mathrm{mg} \mathrm{kg}^{-1}$ (Conde-Cid et al., 2018). Taking into account that these antibiotics are very stable in the dark and are not easily biodegradable (Biošić et al., 2017), other alternatives that could be effective means of inactivation/retention would be especially relevant. For this reason, adsorption/desorption studies have been considered of importance for sulfonamides, and have been carried out in agricultural soils, with results indicating that sulfonamide antibiotics are poorly adsorbed, while suffer high desorption. These facts cause that sulfonamides are highly mobile and bioavailable in the environment, which facilitates its leaching and subsequent incorporation into the food chain (Conde-Cid et al., 2019a, 2020a). In fact, Conde-Cid et al. (2018) found up to $0.6 \mathrm{mg} \mathrm{kg}^{-1}$ of sulfamethazine and up to $0.5 \mathrm{mg} \mathrm{kg}^{-1}$ of sulfadiazine in vegetables grown on Galician soils.

Some previous studies have focused on the study of porous materials as adsorbents for sulfonamides (Akpe et al., 2020; Mendiola-Alvarez et al., 2020; Yang et al., 2011). In addition, in order to increase the capacity to retain sulfonamides in polluted soils, the effects of incorporating different porous by-products (pine bark, "oak ash", and mussel shell) has been previously studied (Conde-Cid et al., 2020b). In these soil + by-product mixtures, pine bark was very effective in increasing the adsorption of sulfonamides, reducing their bioavailability and transport to other media. Therefore, this material could be suitable for being used in in situ bioremediation, increasing the adsorption capacity of soils and decreasing desorption of sulfonamides, mainly due to changes in soil $\mathrm{pH}$ and organic matter content/quality (Conde-Cid et al., 2020a, 2020b).

To note that, in recent years, the use of by-products with high adsorption potential (many of them being porous materials) has been a growing interest, and specifically for being used in soil and water decontamination (Núñez-Delgado et al., 2015). It can be considered a low-cost technique that contributes to improving environmental health, reusing/recycling by-products while retaining pollutants (Cutillas-Barreiro et al., 2014; Paradelo et al., 2017). However, even if multiple investigations have been carried out in this field, the individual capacity of the specific porous materials pine bark, "oak ash" and mussel shell to act as bioadsorbents for sulfonamides present in water has not been studied so far.

In view of that, the objective of this work is to use batch-type adsorption/desorption experiments to elucidate the retention capacity of three porous by-products (pine bark, "oak ash" and mussel shell) as regards three sulfonamide antibiotics widely used in human and animal medicine (sulfadiazine, sulfamethazine, and sulfachloropyridazine). The results of the study could aid to make an appropriate use of these byproducts, facilitating its correct recycling to improve environmental and human health.

\section{Materials and methods}

\subsection{Bioadsorbents}

Two forest by-products were used: the here called "oak ash", which is a solid residue from the combustion of oak chips in a boiler combustion in Lugo (Spain), and pine bark (fraction less than $0.63 \mathrm{~mm}$ ), a commercial product from Geolia (Madrid, Spain). The third by-product was from a food industry, specifically uncalcined mussel shell with a diameter of less than $1 \mathrm{~mm}$, supplied by Abonomar S.L. (Illa de Arousa, Pontevedra, Spain). These three materials were previously characterized by Quintáns-Fondo et al. (2017), and details on them are included in Supplementary Material (Table S1).

\subsection{Chemicals}

The antibiotics were sulfadiazine (SDZ), sulfamethazine (SMT), and sulfachloropyridazine (SCP), with 99.7, 99.6, and 99.7\% purities, respectively, all three provided by Sigma-Aldrich (Barcelona, Spain). Table S2 (Supplementary Material) shows their main characteristics.

As shown in Table S2 (Supplementary Material), these antibiotics are amphoteric, with two values for $\mathrm{pKa}$, which causes that their molecules could be a cation, an anion, or be without charge, as a function of $\mathrm{pH}$ of the medium, although at the most frequent $\mathrm{pH}$ values in the environment they appear predominantly in neutral form.

The other chemicals used in this work were of high purity analytical grade and provided by Panreac (Barcelona, Spain), unless acetonitrile, HPLC grade and supplied by Fisher Scientific (Madrid, Spain). All solutions were prepared using milliQ water, obtained from Millipore equipment (Millipore, Madrid, Spain).

\subsection{Experiments on adsorption/desorption of the antibiotics}

Adsorption/desorption of the three sulfonamides in the three byproducts were studied by means of batch-type experiments. Specifically, a certain amount of by-product ( $2 \mathrm{~g}$ for mussel shell and $0.5 \mathrm{~g}$ for "oak ash" and pine bark) was added with a specific volume of individual solutions of each antibiotic $(5 \mathrm{~mL}$ for mussel shell and $10 \mathrm{~mL}$ for "oak ash" and pine bark), using polypropylene tubes of $15 \mathrm{~mL}$ capacity. Seven different concentrations $\left(2.5,5,10,20,30,40\right.$ and $\left.50 \mu \mathrm{mol} \mathrm{L}^{-1}\right)$ of each of the sulfonamides were used, all of them containing $\mathrm{CaCl}_{2}$ as background electrolyte (used to keep constant the ionic strength).

These suspensions were shaken for $24 \mathrm{~h}$ (time that had been shown to be sufficient to reach equilibrium in preliminary kinetic studies) on a rotary shaker at $50 \mathrm{rpm}$, at room temperature $\left(25 \pm 2{ }^{\circ} \mathrm{C}\right)$ in the dark. The suspensions were then centrifuged $(2665 \times g, 15 \mathrm{~min})$, and filtered ( $0.45 \mu \mathrm{m}$ nylon syringe filters, Fisher scientific, Madrid, Spain). In the filtered liquids, $\mathrm{pH}$ was measured with a combined glass electrode (Crison, Barcelona, Spain) and the concentrations of antibiotics were determined by HPLC-UV (see section 2.4. below). The $\mathrm{pH}$ values were those of the materials in the solutions, as they were not adjusted or buffered by means of any additional chemical reactive. The amount of antibiotic adsorbed was calculated as the difference between that initially added and that present in the solution at equilibrium.

For studying desorption, the precipitates resulting from centrifugation (which had previously been subjected to the adsorption process) were weighed to calculate the volume of occluded solution, then were resuspended in $0.005 \mathrm{M} \mathrm{CaCl}_{2}$ (in $5 \mathrm{~mL}$ in the case of mussel shell, and in $10 \mathrm{~mL}$ for "oak ash" and pine bark) and were shaken, centrifuged, filtered and analyzed in the same way as described for adsorption.

In parallel, blanks without by-products (only with antibiotic) were performed to quantify the possible loss of antibiotic due to degradation and/or adsorption to the tubes or filters, resulting that the loss of antibiotic was $<3 \%$ in all cases. All experiments were carried out in triplicate.

\subsection{Quantification of sulfonamide antibiotics}

Sulfonamides were quantified as indicated by Conde-Cid et al. (2018). For carrying out the analyses, an HPLC equipment (Dionex Corporation, Sunnyvale, USA) was used.

All details are included in Supplementary Material. 


\subsection{Data treatment}

Data from adsorption experiments at equilibrium were described using the Linear (Eq. (1)) and Freundlich (Eq. (2)) models.

$q a=K_{d} C_{e q}$

$q a=K_{F} C_{e q}^{n}$

where $q_{a}\left(\mu \mathrm{mol} \mathrm{kg}{ }^{-1}\right)$ and $C_{e q}\left(\mu \mathrm{mol} \mathrm{L}{ }^{-1}\right)$ are the antibiotic concentrations in the adsorbent material and in the solution at equilibrium, respectively; $K_{d}\left(\mathrm{~L} \mathrm{~kg}^{-1}\right)$ is the distribution coefficient; $K_{F}\left(\mathrm{~L}^{\mathrm{n}} \mu \mathrm{mol}^{1-\mathrm{n}}\right.$ $\mathrm{kg}^{-1}$ ) is the Freundlich affinity coefficient; and $n$ (dimensionless) is the Freundlich linearity index.

Desorption data was expressed as the amount of antibiotic desorbed $\left(\mu \mathrm{mol} \mathrm{kg}^{-1}\right)$, as well as the percentage of antibiotic desorbed with respect to the amount previously adsorbed. The software SPSS 21 for Windows was used to study the fitting of experimental data to models.

\section{Results and discussion}

\subsection{Characteristics of the bioadsorbent materials}

Table S1 (Supplementary Material) shows the characteristics of the sorbent materials studied. Pine bark has a high organic matter content (48.7\%), much higher than that of "oak ash" and mussel shell (13.23 and $11.43 \%$, respectively). These by-products also present very different $\mathrm{pH}_{\mathrm{w}}$ values, with "oak ash" being very alkaline (11.31), followed by mussel shell (9.39), while pine bark is very acidic (3.99). The solid residue from combustion of oak wood, here called "oak ash", is the material with the highest concentration of exchangeable and total alkaline elements (with the exception of total $\mathrm{Ca}$, which is higher in mussel shell), and also of $\mathrm{Al}$, and total "heavy metals", generally obtaining the lowest values in pine bark for all of them. Al and Fe extracted with ammonium oxalate, which estimates the content of these elements in non-crystalline form, is much higher in "oak ash".

\subsection{Adsorption of the sulfonamide antibiotics onto the three different bioadsorbents}

Pine bark is the bioadsorbent with the highest capacity to adsorb each of the three sulfonamides, increasing adsorption as a function of the concentration of antibiotic added. When the concentration of antibiotic added was $50 \mu \mathrm{M}$, the amounts adsorbed were $780 \mu \mathrm{mol} \mathrm{kg}^{-1}$ for SDZ, $890 \mu \mathrm{mol} \mathrm{kg}^{-1}$ for SMT, and $870 \mu \mathrm{mol} \mathrm{kg}{ }^{-1}$ for SCP (Fig. 1). "Oak ash" and mussel shell have low adsorption capacity for the three sulfonamides, showing values always lower than $150 \mu \mathrm{mol} \mathrm{kg}^{-1}$ (oak ash) and $20 \mu \mathrm{mol} \mathrm{kg}^{-1}$ (mussel shell) when a concentration of $50 \mu \mathrm{mol} \mathrm{L}^{-1}$ of antibiotic is added.

Expressed as percentage, pine bark always adsorbs more than $70 \%$ of any of the three sulfonamides. When the lowest concentration of antibiotic is added, SDZ is the sulfonamide that is most adsorbed (up to 90\%), while it is SCP (reaching up to 95\%) for the two highest doses of antibiotic added. "Oak ash" and mussel shell are not very efficient in retaining sulfonamides, with adsorptions lower than $40 \%$ and $15 \%$, respectively, both showing a lower affinity for SDZ (Fig. 2).

The higher adsorption of the three sulfonamides onto pine bark can be related to the high content of organic matter and the acidic $\mathrm{pH}$ (3.99) of this material, since the maximum adsorption of these antibiotics occurs at pH 4-4.25 (Ahmed et al., 2017). Several authors have pointed out that $\mathrm{pH}$ and organic matter are the parameters that most affect the adsorption/desorption processes for sulfonamides, so that when organic matter increases, adsorption increases and desorption decreases, while the opposite behavior takes place when $\mathrm{pH}$ increases (Conde-Cid et al., 2019a, 2019b; 2020a, 2020b; Park and Huwe, 2016; Wang and Wang, 2015). To bear in mind that sulfonamides are amphoteric and can be as
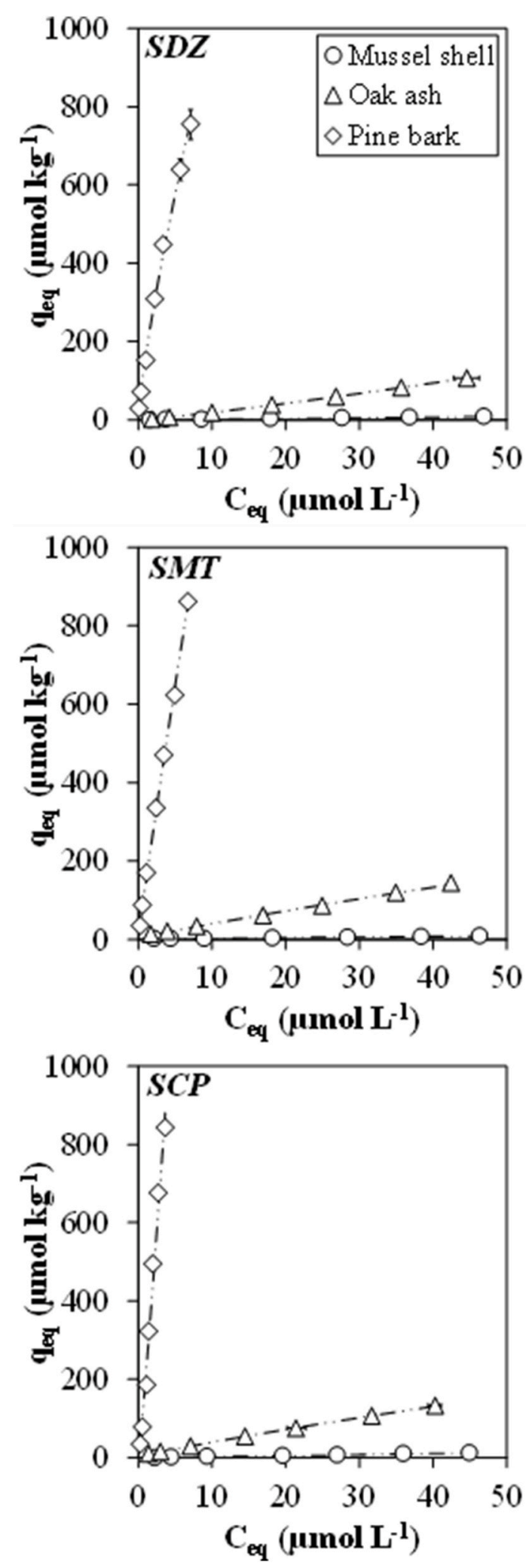

Fig. 1. Adsorption curves for the three sulfonamide antibiotics (sulfadiazine -SDZ, sulfamethazine -SMT and sulfachloropyridazine-SCP) and the three byproducts studied.

cations, zwitterions or as anions, depending on the $\mathrm{pH}$ of the medium. In this way, at $\mathrm{pH} 4$ the cationic species of sulfonamides will adsorb on the deprotonated carboxylic groups of the organic matter of pine bark, this taking place through electrostatic interactions, which is the main 

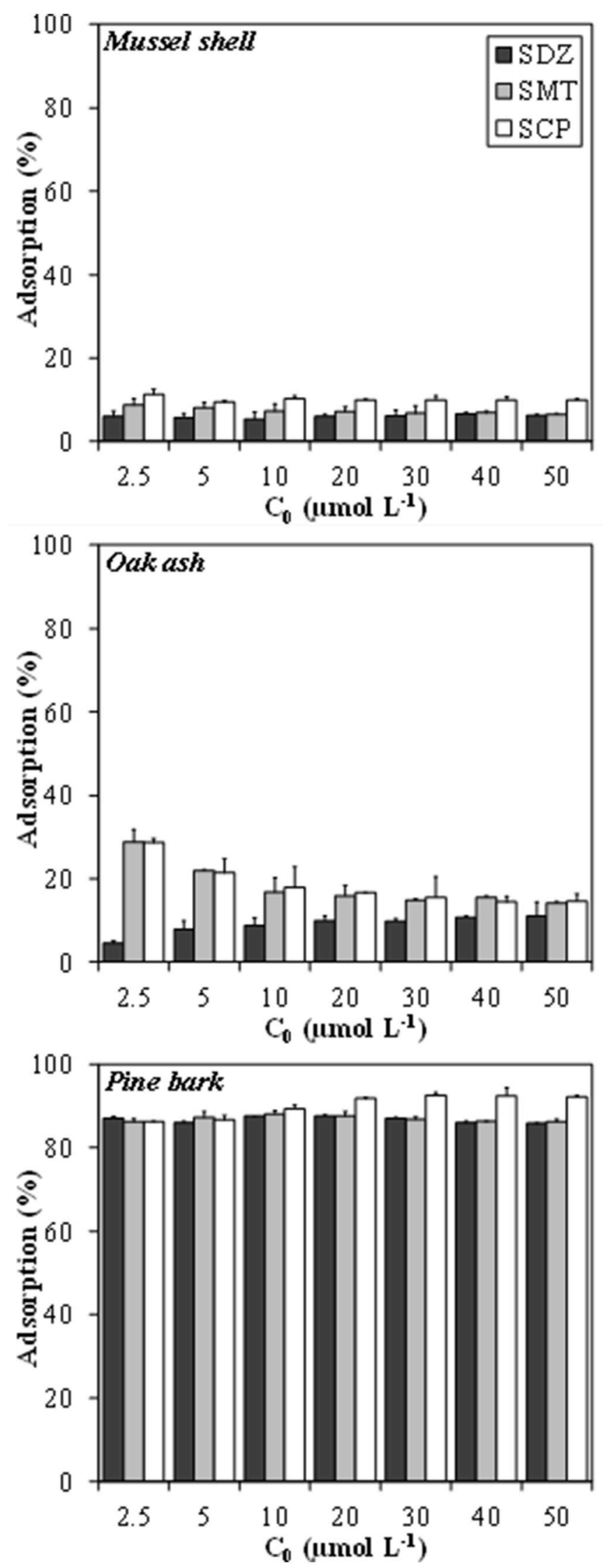

Fig. 2. Percentage adsorption for the three sulfonamide antibiotics (sulfadiazine -SDZ, sulfamethazine -SMT and sulfachloropyridazine -SCP) onto the three by-products and for each of the initial concentrations added. Average values $(n=3)$, with error bars (coefficients of variations $<5 \%$ ). mechanism of adsorption for these antibiotics (Wegst-Uhrich et al., 2014). This is true at very acid pH values, even in other situations hydrophobic partitioning is most relevant (Conde-Cid et al., 2019a). Pine bark has an adsorption capacity 6 times higher than different soils previously tested, even those that showed a greater retention capacity for antibiotics (soils with acidic $\mathrm{pH}$ and high organic matter content) (Conde-Cid et al., 2019b). In the current study, the higher adsorption showed for SCP compared to the other two sulfonamides (Fig. 1) can be related to its hydrophobicity, which is determined by the octanol-water partition coefficient $\left(\mathrm{K}_{\mathrm{OW}}\right)$, and indicates the propensity of the molecules to dissolve in a non-polar medium. Table S2 (Supplementary Material) shows that at acidic $\mathrm{pH}$ (such as that found for pine bark), the log $\mathrm{K}_{\mathrm{OW}}$ is higher for SCP, which indicates a higher hydrophobicity of this antibiotic with respect to the other two sulfonamides, and therefore a higher tendency to adsorption. In acid soils, a higher adsorption of SCP has also been reported (Conde-Cid et al., 2019a).

The lower adsorption of sulfonamides onto "oak ash" and mussel shell could be related to the high $\mathrm{pH}$ of these by-products, making that the anionic species of sulfonamides predominate, which can therefore be repelled by the negative charges present on the surface of the organic matter of the adsorbents. In this situation, the adsorbent/sorbate bond would need to take place by means of a cationic bridge, an adsorption mechanism that is not frequent for antibiotics of this group (Wegst-Uhrich et al., 2014). "Oak ash" has a high content of organic matter, but its alkaline $\mathrm{pH}$ (11.3) makes the anionic species predominate in sorbent and sorbate, so adsorption is low, causing that this by-product would not be sufficiently effective in decontamination of water, as it would only retain a maximum of $40 \%$ of the sulfonamides studied when concentrations are less than $5 \mu \mathrm{mol} \mathrm{L}{ }^{-1}$ (Fig. 2). Regarding mussel shell, sulfonamide adsorption is always less than $10 \%$ of the concentration added, which can be related to the lower content of organic matter and the alkaline $\mathrm{pH}$ (9.4) of the by-product.

In all cases, adsorption data adjusted well to the Linear and Freundlich models, with $\mathrm{R}^{2}$ values between 0.98 and 1.00 (Table 1 ). The $K_{d}$ (linear model) and Freundlich's $K_{F}$ values were very similar to each other for the same antibiotic and sorbent (in the ranges $0.17-253.67 \mathrm{~L}$ $\mathrm{kg}^{-1}$ and $0.14-202.26 \mathrm{~L}^{\mathrm{n}} \mu \mathrm{mol}^{1-\mathrm{n}} \mathrm{kg}^{-1}$, respectively), and are more similar as the value of $n$ is closer to 1 (in fact, when $n$ is 1 the Freundlich equation becomes a linear equation). Similar values for these two parameters were also obtained with different antibiotics in soils (Conde-Cid et al., 2019b). In the current study, the sequence followed by the $K_{d}$ and $K_{F}$ values for the three antibiotics in these by-products is: SDZ <

Table 1

Fitting of adsorption data to the Linear and Freundlich models. $K_{d}\left(\mathrm{~L} \mathrm{~kg}^{-1}\right)$ : distribution coefficient; $K_{F}\left(\mathrm{~L}^{\mathrm{n}} \mu \mathrm{mol}^{1-\mathrm{n}} \mathrm{kg}^{-1}\right)$ : Freundlich's affinity coefficient; $n$ (dimensionless): Freundlich's linearity index. SDZ: sulfadiazine; SMT: sulfamethazine; SCP: sulfachloropyridazine.

\begin{tabular}{|c|c|c|c|c|c|c|}
\hline \multirow{2}{*}{$\begin{array}{l}\text { By- } \\
\text { product }\end{array}$} & \multirow[t]{2}{*}{ Antibiotic } & \multicolumn{2}{|l|}{ Linear } & \multicolumn{3}{|l|}{ Freundlich } \\
\hline & & $K_{d}$ & $\mathrm{R}^{2}$ & $K_{F}$ & $n$ & $\mathrm{R}^{2}$ \\
\hline \multirow[t]{3}{*}{$\begin{array}{r}\text { Mussel } \\
\text { shell }\end{array}$} & SDZ & $\begin{array}{l}0.17 \pm \\
0.01\end{array}$ & 0.994 & $\begin{array}{l}0.14 \pm \\
0.03\end{array}$ & $\begin{array}{l}1.04 \pm \\
0.06\end{array}$ & 0.995 \\
\hline & SMT & $\begin{array}{l}0.17 \pm \\
0.00\end{array}$ & 1.000 & $\begin{array}{l}0.23 \pm \\
0.01\end{array}$ & $\begin{array}{l}0.93 \pm \\
0.01\end{array}$ & 1.000 \\
\hline & SCP & $\begin{array}{l}0.28 \pm \\
0.00\end{array}$ & 1.000 & $\begin{array}{l}0.29 \pm \\
0.01\end{array}$ & $\begin{array}{l}0.99 \pm \\
0.01\end{array}$ & 1.000 \\
\hline \multirow[t]{3}{*}{ Oak ash } & SDZ & $\begin{array}{l}2.47 \pm \\
0.06\end{array}$ & 0.997 & $\begin{array}{l}1.25 \pm \\
0.05\end{array}$ & $\begin{array}{l}1.17 \pm \\
0.01\end{array}$ & 1.000 \\
\hline & SMT & $\begin{array}{l}3.16 \pm \\
0.02\end{array}$ & 1.000 & $\begin{array}{l}5.45 \pm \\
0.71\end{array}$ & $\begin{array}{l}0.87 \pm \\
0.04\end{array}$ & 0.996 \\
\hline & SCP & $\begin{array}{l}3.15 \pm \\
0.03\end{array}$ & 0.999 & $\begin{array}{l}5.62 \pm \\
0.41\end{array}$ & $\begin{array}{l}0.85 \pm \\
0.02\end{array}$ & 0.999 \\
\hline \multirow[t]{3}{*}{ Pine bark } & SDZ & $\begin{array}{l}104.68 \pm \\
4.86\end{array}$ & 0.987 & $\begin{array}{l}157.42 \pm \\
7.24\end{array}$ & $\begin{array}{l}0.81 \pm \\
0.03\end{array}$ & 0.998 \\
\hline & SMT & $\begin{array}{l}125.27 \pm \\
2.61\end{array}$ & 0.997 & $\begin{array}{l}141.92 \pm \\
5.54\end{array}$ & $\begin{array}{l}0.94 \pm \\
0.02\end{array}$ & 0.999 \\
\hline & SCP & $\begin{array}{l}253.67 \pm \\
11.82\end{array}$ & 0.989 & $\begin{array}{l}202.76 \pm \\
20.42\end{array}$ & $\begin{array}{l}1.28 \pm \\
0.09\end{array}$ & 0.984 \\
\hline
\end{tabular}


SMT $<$ SCP (Table 1 ), a sequence that has been previously reported by other authors (Conde-Cid et al., 2019b; Pereira-Leal et al., 2013; Rath et al., 2019). Regarding the sequence of the $K_{d}$ and $K_{F}$ values of these antibiotics for the three by-products (instead of for the three antibiotics), it was: pine bark $\gg>$ oak ash $>$ mussel shell, which coincides with the adsorption values commented above (Fig. 1).

The $K_{F}$ value (related to the adsorption capacity of an adsorbent) obtained for the three sulfonamides, in the case of pine bark is 38 times greater than the mean value of this parameter obtained for 50 crop soils (Conde-Cid et al., 2019a). Furthermore, Conde-Cid et al. (2020a) indicate that the addition of $48 \mathrm{Mg} \mathrm{ha}^{-1}$ of pine bark to a crop soil with $K_{F}$ values of 1.9, 2.9 and $1.2 \mathrm{~L}^{\mathrm{n}} \mu \mathrm{mol}^{1-\mathrm{n}} \mathrm{kg}^{-1}$ for SDZ, SMT and SCP, respectively, clearly increased the adsorption capacity for these antibiotics in that soil, obtaining $K_{F}$ values of $5.6 \mathrm{~L}^{\mathrm{n}} \mu \mathrm{mol}^{1-\mathrm{n}} \mathrm{kg}^{-1}$ for SDZ, 8.8 $\mathrm{L} \mathrm{kg}^{-1}$ for SMT and $7.1 \mathrm{~L}^{\mathrm{n}} \mu \mathrm{mol}^{1-\mathrm{n}} \mathrm{kg}^{-1}$ for SCP. However, these $K_{F}$ values of the soil + pine bark mixtures are much lower than that of the bark alone, specifically 28 times lower for SDZ and SCP, and 16 times lower in the case of SMT.

The $n$ parameter of the Freundlich equation indicates the reactivity and heterogeneity of the active sites of an adsorbent. If $n=1$ the adsorption is linear, if $n>1$ the adsorption process is mainly chemical, and if $n<1$ it indicates that physical adsorption is more favorable, with adsorption sites being heterogeneous, those of high energy being the first to be occupied, and with strong interactions taking place between sorbate molecules (Conde-Cid et al., 2019c). In the present study, $n$ values ranged between 0.81 and 1.28 , although they were generally $<1$ (unless in three cases) (Table 1), which indicates the presence of high-energy sites and cooperative-type adsorption. In the case of pine bark, which is the by-product with the highest adsorption capacity, the value of $n$ is $>1(n=1.28)$ for SCP (Table 1$)$, which indicates a high affinity of that antibiotic for adsorption sites, and also a high binding energy.

\subsection{Desorption of the three sulfonamide antibiotics}

Table 2 shows both desorption values and percentage desorbed for each of the antibiotics and for the different concentrations added. The percentage of sulfonamides desorbed ranged between 19 and $81 \%$ for mussel shell, between 0 and $49 \%$ for "oak ash", and it was always less than $11 \%$ for pine bark, even when the highest doses of antibiotics were added.

Considering both adsorption and desorption data for the three sulfonamides and the three by-products, it is shown that pine bark adsorbs practically $90 \%$ of the antibiotic added, almost in an irreversible way. In previous works (Conde-Cid et al., 2020b) it has been found that sulfonamides have high mobility (low retention) in agricultural soils, and that the incorporation of pine bark increases the retention of these antibiotics, reducing their availability and the risk of entering the food chain. The results of the current study allow us to affirm that, in addition to interacting with the soil and then increase adsorption capacity, pine bark itself has a high adsorbing potential for sulfonamides, and can be considered as a material that could be used in water treatment processes, when liquids are contaminated with these antibiotics.

On the contrary, "oak ash", which in previous studies performed as an excellent adsorbent for tetracycline antibiotics (Conde-Cid et al., 2019c), is not suitable for the retention of sulfonamides, showing low adsorption and high desorption for these last antibiotics. To take into account that tetracyclines can be adsorbed by different mechanisms (electrostatic interactions, complexation, cationic bridges, $\mathrm{H}$ bonds -Wang and Wang, 2015-) while electrostatic attractions are the predominant and almost exclusive mechanism for sulfonamides (Wegst-Uhrich et al., 2014), which reduces the possibility of interacting with the functional groups of sorbents. Mussel shell does not effectively retain tetracyclines (as evidenced by Conde-Cid et al., 2019c) or sulfonamides, as evidenced in the present work.
Table 2

Desorbed amounts (and percentages between brackets) for each of the three sulfonamide antibiotics and for each by-product, considering each of the initial concentration added $\left(C_{O}\right)$. SDZ: sulfadiazine; SMT: sulfamethazine; SCP: sulfachloropyridazine. Average values for three triplicates, with coefficients of variation always $<5 \%$.

\begin{tabular}{|c|c|c|c|c|c|c|c|c|}
\hline & & \multicolumn{7}{|c|}{$\mathrm{C}_{0}\left(\mu \mathrm{mol} \mathrm{L}^{-1}\right)$} \\
\hline & & 2.5 & 5 & 10 & 20 & 30 & 40 & 50 \\
\hline \multirow[t]{3}{*}{$\begin{array}{r}\text { Mussel } \\
\text { shell }\end{array}$} & SDZ & $\begin{array}{l}0.1 \\
(33)\end{array}$ & $\begin{array}{l}0.8 \\
(76)\end{array}$ & $\begin{array}{l}1.0 \\
(65)\end{array}$ & $\begin{array}{l}1.4 \\
(50)\end{array}$ & $\begin{array}{l}2.1 \\
(48)\end{array}$ & $\begin{array}{l}4.1 \\
(63)\end{array}$ & $\begin{array}{l}5.2 \\
(67)\end{array}$ \\
\hline & SMT & $\begin{array}{l}0.2 \\
(42)\end{array}$ & $\begin{array}{l}0.4 \\
(47)\end{array}$ & $\begin{array}{l}1.1 \\
(60)\end{array}$ & $\begin{array}{l}1.8 \\
(53)\end{array}$ & $\begin{array}{l}3.1 \\
(63)\end{array}$ & $\begin{array}{l}3.8 \\
(57)\end{array}$ & $\begin{array}{l}5.1 \\
(63)\end{array}$ \\
\hline & SCP & $\begin{array}{l}0.1 \\
(19)\end{array}$ & $\begin{array}{l}0.4 \\
(30)\end{array}$ & $\begin{array}{l}1.4 \\
(55)\end{array}$ & $\begin{array}{l}2.7 \\
(74)\end{array}$ & $\begin{array}{l}6.1 \\
(81)\end{array}$ & $\begin{array}{l}7.1 \\
(72)\end{array}$ & $\begin{array}{l}9.8 \\
(79)\end{array}$ \\
\hline \multirow[t]{3}{*}{ Oak ash } & SDZ & $0(0)$ & $\begin{array}{l}0.5 \\
(8)\end{array}$ & $\begin{array}{l}1.5 \\
(8)\end{array}$ & $\begin{array}{l}3.2 \\
(8)\end{array}$ & $\begin{array}{l}5.6 \\
(10)\end{array}$ & $\begin{array}{l}9.6 \\
(12)\end{array}$ & $\begin{array}{l}18.8 \\
(15)\end{array}$ \\
\hline & SMT & $\begin{array}{l}6.1 \\
(49)\end{array}$ & $\begin{array}{l}7.7 \\
(37)\end{array}$ & $\begin{array}{l}9.9 \\
(31)\end{array}$ & $\begin{array}{l}11.8 \\
(19)\end{array}$ & $\begin{array}{l}14.3 \\
(17)\end{array}$ & $\begin{array}{l}15.8 \\
(14)\end{array}$ & $\begin{array}{l}21.9 \\
(15)\end{array}$ \\
\hline & SCP & $0(0)$ & $\begin{array}{l}0.7 \\
(4)\end{array}$ & $\begin{array}{l}1.7 \\
(5)\end{array}$ & $\begin{array}{l}6.1 \\
(11)\end{array}$ & $\begin{array}{l}8.7 \\
(12)\end{array}$ & $\begin{array}{l}12.1 \\
(11)\end{array}$ & $\begin{array}{l}15.0 \\
(11)\end{array}$ \\
\hline \multirow[t]{3}{*}{$\begin{array}{l}\text { Pine } \\
\text { bark }\end{array}$} & SDZ & $\begin{array}{l}2.3 \\
(8)\end{array}$ & $\begin{array}{l}2.6 \\
(4)\end{array}$ & $\begin{array}{l}6.4 \\
(4)\end{array}$ & $\begin{array}{l}20.6 \\
(7)\end{array}$ & $\begin{array}{l}35.4 \\
(8)\end{array}$ & $\begin{array}{l}39.4 \\
(6)\end{array}$ & $\begin{array}{l}40.2 \\
\text { (5) }\end{array}$ \\
\hline & SMT & $\begin{array}{l}2.1 \\
(6)\end{array}$ & $\begin{array}{l}7.5 \\
(9)\end{array}$ & $\begin{array}{l}10 \\
(6)\end{array}$ & $\begin{array}{l}12.0 \\
(4)\end{array}$ & $\begin{array}{l}15.3 \\
(3)\end{array}$ & $\begin{array}{l}22.0 \\
(4)\end{array}$ & $\begin{array}{l}33.6 \\
(4)\end{array}$ \\
\hline & SCP & $\begin{array}{l}3.8 \\
(11)\end{array}$ & $\begin{array}{l}8.9 \\
(11)\end{array}$ & $\begin{array}{l}10.2 \\
(6)\end{array}$ & $\begin{array}{l}19.2 \\
(6)\end{array}$ & $\begin{array}{l}21.5 \\
(4)\end{array}$ & $\begin{array}{l}24.4 \\
\text { (4) }\end{array}$ & $\begin{array}{l}32.6 \\
(4)\end{array}$ \\
\hline
\end{tabular}

\section{Conclusions}

Among the three by-products studied, pine bark was the bioadsorbent that showed the highest capacity to adsorb the sulfonamide antibiotics sulfodiazine, sulfomethazine and sulfochloropyridazine. In addition, the retention was practically irreversible, making that pine bark could be used in water treatment, or to remediate other media contaminated with these antibiotics. The strong acidity of pine bark, together with its high content in organic matter, are decisive in this strong retention. "Oak ash" and mussel shell do not show sufficient efficiency to retain the three sulfonamides, as they have a low adsorption capacity and a high desorption rate for these antibiotics, which is greatly affected by its alkaline character. These results could aid to make an appropriate reuse/recycling of the by-products studied, contributing to improve human and environmental health.

\section{Author contributions}

Manuel Conde-Cid: Methodology; Writing - review \& editing; Software; Methodology; Formal analysis; Investigation. Raquel CelaDablanca: Software; Methodology; Formal analysis; Investigation. Gustavo Ferreira-Coelho: Software; Formal analysis; Formal analysis; Investigation. David Fernández-Calviño: Conceptualization; Funding acquisition; Methodology; Investigation. Avelino Núñez-Delgado: Conceptualization; Funding acquisition; Methodology; Investigation; Writing - original draft; Writing - review \& editing; Supervision Resources; Validation; Visualization. María J. Fernández-Sanjurjo: Conceptualization; Data curation; Funding acquisition; Writing - original draft; Investigation; Supervision; Resources; Validation; Visualization. Manuel Arias-Estévez: Conceptualization; Funding acquisition; Investigation; Methodology; Writing - review \& editing; Supervision; Project administration; Resources; Validation; Visualization. Esperanza Álvarez-Rodríguez: Conceptualization; Funding acquisition; Data curation; Writing - original draft; Software; Supervision; Methodology; Project administration; Resources; Validation; Visualization.

\section{Declaration of competing interest}

The authors declare that they have no known competing financial interests or personal relationships that could have appeared to influence the work reported in this paper. 


\section{Acknowledgements}

Funding: This work was supported by the Spanish Ministry of science, innovation and universities [grant numbers RTI2018-099574-BC21 and RTI2018-099574-B-C22]. It also received funds from the European Regional Development Fund (ERDF) (FEDER in Spain), being a complement to the previous grants, without additional grant number. $\mathrm{M}$. Conde-Cid holds a pre-doctoral contract (FPU15/0280, Spanish Government). The research of Dr. Gustavo F. Coelho was also supported by the Improving Coordination of Senior Staff (CAPES), Post-Doctoral Program Abroad (PDE) Process number \{88881.172297/2018-01\} of the Brazilian Government. The sponsors had not involvement in study design; in the collection, analyses and interpretation of data; in the writing of the report, and in the decision to submit the article for publication.

\section{Appendix A. Supplementary data}

Supplementary data to this article can be found online at https://doi. org/10.1016/j.envres.2021.110814.

\section{References}

Ahmed, M.B., Zhou, J.L., Ngo, H.H., Guo, W., Johir, M.A.H., Belhaj, D., 2017. Competitive sorption affinity of sulfonamides and chloramphenicol antibiotics toward functionalized biochar for water and wastewater treatment. Bioresour. Technol. 238, 306-312. https://doi.org/10.1016/j.biortech.2017.04.042.

Akpe, S.G., Ahmed, I., Puthiaraj, P., Yu, K., Ahn, W.S., 2020. Microporous organic polymers for efficient removal of sulfamethoxazole from aqueous solutions. Microporous Mesoporous Mater. 296, 109979. https://doi.org/10.1016/j. micromeso.2019.109979.

Alduina, R., 2020. Antibiotics and environment. Antibiotics 9 (4), 202. https://doi.org/ 10.3390/antibiotics9040202.

Barber, L.B., Keefe, S.H., LeBlanc, D.R., Bradley, P.M., Chapelle, F.H., Meyer, M.T., Loftin, K.A., Kolpin, D.W., Rubio, F., 2009. Fate of sulfamethoxazole, 4-nonylphenol, and $17 \mathrm{~B}$-estradiol in groundwater contaminated by wastewater treatment plant effluent. Environ. Sci. Technol. 43, 4843-4850. https://doi.org/10.1021/ es803292v.

Biošić, M., Mitrevski, M., Babic, S., 2017. Environmental behaviour of sulfadiazine, sulfamethazine, and their metabolites. Environ. Sci. Pollut. Control Ser. 24, 9802-9812. https://doi.org/10.1007/s11356-017-8639-8.

Carvalho, I.T., Santos, L., 2016. Antibiotics in the aquatic environments: a review of the European scenario. Environ. Int. 94, 736-757. https://doi.org/10.1016/j. envint. 2016.06.025.

Conde-Cid, M., Álvarez-Esmorís, C., Paradelo-Núñez, R., Novoa-Muñoz, J.C., AriasEstévez, M., Álvarez-Rodríguez, E., Fernández-Sanjurjo, M.J., Núñez-Delgado, A., 2018. Occurrence of tetracyclines and sulfonamides in manures, agricultural soils and crops from different areas in Galicia (NW Spain). J. Clean. Prod. 197, 491-500. https://doi.org/10.1016/j.jclepro.2018.06.217.

Conde-Cid, M., Novoa-Muñoz, J.C., Núñez-Delgado, A., Fernández-Sanjurjo, M.J., AriasEstevez, M., Álvarez-Rodríguez, E., 2019a. Experimental data and modeling for sulfachloropyridazine and sulfamethazine adsorption/desorption on agricultural acid soils. Microporous Mesoporous Mater. 288, 109601-209611. https://doi.org/ 10.1016/j. mecromeso.2019.109601.

Conde-Cid, M., Fernández-Calviño, D., Fernández-Sanjurjo, M.J., Núñez-Delgado, A., Alvarez-Rodríguez, E., Arias-Estévez, M., 2019b. Adsorption/desorption and transport of sulfadiazine, sulfachloropyridazine, and sulfamethazine, in acid agricultural soils. Chemosphere 234, 978-986. https://doi.org/10.1016/j. chemosphere.2019.06.121.

Conde-Cid, M., Ferreira-Coelho, Gustavo, Arias-Estévez, M., Cristina Álvarez-Esmorís, C., Nóvoa-Muñoz, J.C., Núñez-Delgado, A., Fernández-Sanjurjo, M.J., ÁlvarezRodríguez, E., 2019c. Competitive adsorption/desorption of tetracycline, oxytetracycline and chlortetracycline on pine bark, oak ash and mussel shell. J. Environ. Manag. 250, 109509. https://doi.org/10.1016/j.jenvman.2019.109509.

Conde-Cid, M., Ferreira-Coelho, G., Fernández-Calviño, D., Núñez-Delgado, A., Fernández-Sanjurjo, M.J., Arias-Estévez, M., Álvarez-Rodríguez, E., 2020a. Single and simultaneous adsorption of three sulfonamides in agricultural soils: effects of $\mathrm{pH}$ and organic matter content. Sci. Total Environ. 744, 140872-140886. https://doi. org/10.1016/j.scitotenv.2020.140872.

Conde-Cid, M., Fernandez-Calviño, D., Núñez-Delgado, A., Fernandez-Sanjurjo, M.J., Arias-Estevez, M., Alvarez-Rodríguez, E., 2020b. Influence of mussel shell, oak ash and pine bark on the adsorption and desorption of sulfonamides in agricultural soils. J. Environ. Manag. 261 https://doi.org/10.1016/j. jenvman.2020.110221, 110221110131.
Cutillas-Barreiro, L., Ansias-Manso, L., Fernández-Calviño, D., Arias-Estévez, M., NóvoaMuñoz, J.C., Fernández-Sanjurjo, M.J., Álvarez-Rodríguez, E., Núñez-Delgado, A., 2014. Pine Bark as bio-adsorbent for $\mathrm{Cd}, \mathrm{Cu}, \mathrm{Ni}, \mathrm{Pb}$ and $\mathrm{Zn}$ : batch-type and stirred flow chamber experiments. J. Environ. Manag. 114, 258-264. https://doi.org/ 10.1016/j.jenvman.2014.06.008.

Jechalke, S., Heuer, H., Siemens, J., Amelung, W., Kornelia Smalla, K., 2014. Fate and effects of veterinary antibiotics in soil. Trends Microbiol. 22 (9), 536-545. https:// doi.org/10.1016/j.tim.2014.05.005.

Lahcen, A.A., Amine, A., 2018. Mini-review: recent advances in electrochemical determination of sulfonamides. Anal. Lett. 51, 424-441. https://doi.org/10.1080/ 00032719.2017.1295977.

Lou, Y., Ye, X., Ye, Z.L., Chiang, P.C., Chen, S., 2018. Occurrence and ecological risks of veterinary antibiotics in struvite recovered from swine wastewater. J. Clean. Prod. 201, 678-685. https://doi.org/10.1016/j.jclepro.2018.08.012.

Mendiola-Alvarez, S.Y., Turnes-Palomino, G., Guzmán-Mar, J., Hernández-Ramírez, A., Hinojosa-Reyes, L., Palomino-Cabello, C., 2020. Magnetic porous carbons derived from cobalt(II)-based metal-organic frameworks for the solid phase extraction of sulfonamides. Dalton Trans. 49, 8959. https://doi.org/10.1039/d0dt01215g.

Núñez-Delgado, A., Álvarez-Rodríguez, E., Fernández-Sanjurjo, M.J., Nóvoa-Muñoz, J.C., Arias-Estévez, M., Fernández-Calviño, D., 2015. Perspectives on the use of byproducts to treat soil and water pollution. Microporous Mesoporous Mater. 210, 199-201. https://doi.org/10.1016/j.micromeso.2015.02.001.

Paolotti, L., Boggia, A., Castellini, C., Rocchi, L., Rosati, A., 2016. Combining livestock and tree crops to improve sustainability in agriculture: a case study using the life cycle assessment (LCA) approach. J. Clean. Prod. 131, 351-363. https://doi.org/ 10.1016/j. jclepro.2016.05.024.

Paradelo, R., Conde-Cid, M., Arias-Estévez, M., Novoa-Muñoz, J.C., AlvarezRodríguez, E., Fernandez-Sanjurjo, M.J., Núñez-Delgado, A., 2017. Removal of anionic pollutants by pine bark is influenced by the mechanism of retention. Chemosphere 167, 139-145. https://doi.org/10.1016/j.chemosphere.2016.09.158.

Park, J.Y., Huwe, B., 2016. Effect of $\mathrm{pH}$ and soil structure on transport of sulfonamide antibiotics in agricultural soils. Environ. Pollut. 213, 561-570. https://doi.org/ 10.1016/j.envpol.2016.01.089.

Pereira-Leal, R.M., Ferracciú-Alleoni, L.R., Luiz-Tornisielo, V., Borges-Regitano, J., 2013. Sorption of fluoroquinolones and sulfonamides in 13 Brazilian soils. Chemosphere 92, 979-985. https://doi.org/10.1016/j.chemosphere.2013.03.018.

Qiao, M., Ying, G.G., Singer, A.C., Zhu, Y.C., 2018. Review of antibiotic resistance in China and its environment. Environ. Int. 110, 160-172. https://doi.org/10.1016/j. envint.2017.10.016.

Quintáns-Fondo, A., Fernández-Calviño, D., Nóvoa-Muñoz, J.C., Arias-Estévez, M., Fernández-Sanjurjo, M.J., Álvarez-Rodríguez, E., Núñez-Delgado, A., 2017. As(V) sorption/desorption on different waste materials and soil samples. Int. J. Environ. Res. Publ. Health 14, 803-813. https://doi.org/10.3390/ijerph14070803.

Ramírez-Malule, H., Quiñones-Murillo, D.H., Manotas-Duque, D., 2020. Emerging contaminants as global environmental hazards. A bibliometric analysis. Emerging Contaminants 6, 179-193. https://doi.org/10.1016/j.emcon.2020.05.001.

Rasheed, T., Bilal, M., Nabeel, F., Adeel, M., Iqbal, H.M.N., 2019. Environmentallyrelated contaminants of high concern: potential sources and analytical modalities for detection, quantification, and treatment. Environ. Int. 122, 52-66. https://doi.org/ 10.1016/j.envint.2018.11.038.

Rath, S., Fostier, A.H., Pereira, L.A., Dionisio, A.C., Ferreira, F.O., Doretto, K.M., Peruchi, L.M., Viera, A., Neto, O.F.O., Bosco, S.M.D., Martínez-Mejía, M.J., 2019. Sorption behaviors of antimicrobial and antiparasitic veterinary drugs on subtropical soils. Chemosphere 214, 111-122. https://doi.org/10.1016/j. chemosphere.2018.09.083.

Singer, A.C., Shaw, H., Rhodes, V., Hart, A., 2016. Review of antimicrobial resistance in the environment and its relevance to environmental regulators. Front. Microbiol. 7, 1728. https://doi.org/10.3389/fmicb.2016.01728.

Spielmeyer, A., Höper, H., Hamscher, G., 2017. Long-term monitoring of sulphonamide leaching from manure amended soil into groundwater. Chemosphere 177, 232-238. https://doi.org/10.1016/j.chemosphere.2017.03.020.

Szymańska, U., Wiergowski, M., Sołtyszewski, I., Wiergowska, G., Woźniak, M.K., 2019. Presence of antibiotics in the aquatic environment in Europe and their analytical monitoring: recent trends and perspectives. Microchem. J. 147, 729-740. https:// doi.org/10.1016/j.microc.2019.04.003.

Wang, S., Wang, H., 2015. Adsorption behavior of antibiotic in soil environment: a critical review. Front. Environ. Sci. Eng. 9, 565-574. https://doi.org/10.1007/ s11783-015-0801-2.

Wegst-Uhrich, S.R., Navarro, D.A.G., Zimmerman, L., Aga, D.S., 2014. Assessing antibiotic sorption in soil: a literature review and new case studies on sulfonamides and macrolides. Chem. Cent. J. 8, 5-10. https://doi.org/10.1186/1752-153X-8-5.

Yang, W., Zheng, F., Xue, X., Lu, Y., 2011. Investigation into adsorption mechanisms of sulfonamides onto porous adsorbents. J. Colloid Interface Sci. 362 (2), 503-509. https://doi.org/10.1016/j.jcis.2011.06.071.

Yang, C.W., Hsiao, W.C., Chang, B.V., 2016. Biodegradation of sulfonamide antibiotics in sludge. Chemosphere 150, 559-565. https://doi.org/10.1016/j. chemosphere.2016.02.064.

Yi, X., Lin, C., Jie, E., Ong, Li, Wang, M., Zhou, Z., 2019. Occurrence and distribution of trace levels of antibiotics in surface waters and soils driven by non-point source pollution and anthropogenic pressure. Chemosphere 216, 213-223. https://doi.org/ 10.1016/j.chemosphere.2018.10.087. 